\title{
Do Caminho à Trilha. As perspectivas do lazer e do habitar na Transcarioca ${ }^{1}$
}

Luz Stella Rodríguez Cáceres*

0 nosso céu é vosso chão

José E. Agualusa-Teoria Geral do Esquecimento

\section{Resumo}

A tensão entre as perspectivas do habitar e do lazer é analisada aqui a partir da experiência dos moradores do maciço da Pedra Branca (RJ), que tradicionalmente o têm habitado e que têm sofrido as consequências da transformação do seu lugar em unidade de conservação ambiental. Mais além e dos conflitos emanados das restrições de usos de espaço para os moradores do parque, esta reflexão procura entender o confronto de visões, interesses e experiências ambientais existentes entre as perspectivas dos habitantes locais e da população urbana visitante. A aspiração a usufruir da oferta ambiental por parte de segmentos urbanos, longe de ser homogênea, alimenta-se de contrastantes e particulares "expectativas de natureza" que nem sempre comungam com os desejos dos ambientalistas e promotores de trilhas ao interior do Parque Estadual Pedra Branca. Essas trilhas têm sua origem nos caminhos de ocupação e comércio históricos e estão vinculadas à ocupação da área e modos de vida rural.

\section{Palavras-chave}

Habitar. Meio ambiente. Turismo.

\section{Abstract}

The tension between the perspectives of living and leisure is analyzed here based on the experience of residents of the Pedra Branca massif (Rio de Janeiro), which have been living

\footnotetext{
${ }^{1}$ Este trabalho contou com o apoio da Fundação Carlos Chagas Filho de Amparo à Pesquisa do Estado do Rio de Janeiro (FAPERJ). Sou grata à acolhida de Pedro Mesquita e sua família na sua casa durante os meses de trabalho de campo, sua receptividade à minha companhia e perguntas foram fundamentais para o desenvolvimento da pesquisa. Agradeço a Raquel Paterman a leitura e comentários deste artigo.

* Luz Stella Rodríguez Cáceres é Antropóloga. Doutora em Geografia e pesquisadora do Laboratório de Antropologia da Arquitetura e Espaços (LAARES), vinculado Instituto de Filosofia e Ciências Sociais (IFCS) da Universidade Federal do Rio de Janeiro (UFRJ). E-mail: lunsella@gmail.com.
} 
there traditionally and have been suffering the consequences of the transformation of their home in a unity of environmental protection. Furthermore, with the conflicts generated by the restriction of space use for the residents, this reflection intends to understand the confrontation of visions, interests and environmental experiences which exist between the perspective of local residents and the visiting urban population. The aspiration to enjoy the environment by the urban segments, which are far from being homogenous, feeds itself of contrasting and particular "nature expectations", which not always agree with the desires of environmentalists and trail promoters inside the Pedra Branca State Park. These trails have their origins in the historic paths of occupation and commerce and are linked to the occupation of the area and the rural lifestyle.

\section{Keywords}

Inhabiting. Environment. Tourism.

\section{Introdução}

Os caminhos usados pelos habitantes e agricultores do maciço da Pedra Branca (RJ) na vertente de Vargem Grande são uma paisagem que delineia imbricações entre humanos, não humanos e ambiente. O uso desses caminhos não é apenas utilitário e está a trelado a um universo de relações de parentesco, tramas de significados e vínculos de pertencimento e envolvimento afetivo que configuram uma singular prática espacial. $O$ conjunto dessas relações é visto a partir da perspectiva do habitar proposta por Heidegger (2002), segundo a qual as coisas não são entidades dadas no espaço objetivo às quais o espirito humano atribui significado posteriormente, pois elas são parte do universo habitado.

Por sua vez, os habitantes do maciço não são os únicos a se servirem dos caminhos que eles mesmos têm urdido ao longo da sua presença centenária. Eles vêm partilhando a paisagem com outros "usuários", que fazem uma apropriação desses espaços partindo do que proponho chamar de "perspectivas do lazer". Elas estão presentes nas casas de veraneio, caminhadas, pedaladas, cavalgadas e motocross, atividades que têm como denominador comum o desfrute do ócio e do tempo livre, perto da natureza, do qual usufruem segmentos da população urbana do Rio de Janeiro.

Visitas turísticas não representam novidade para os habitantes locais, porém sua intensificação e sua recente institucionalização - dadas na 
divulgação de mapas de trilhas para montanhistas e no planejamento da Trilha Transcarioca - equacionam as perspectivas do lazer e as perspectivas do habitar de modo a deixar transparecer suas tensões, expondo que o chamado turismo de natureza não é alheio a conflitos sociais.

Partindo de uma abordagem fenomenológica, sabe-se que existem tantos espaços quantas experiências espaciais distintas (MERLEAU PONTY, 1976; DE CERTEAU, 2013). A percepção do espaço encontra-se necessariamente ligada às vivências das pessoas e dos grupos sociais, razão pela qual não é possível universalizar as relações que cada um chega a estabelecer com a natureza. Distintas experiências geram diversas percepções sobre um mesmo espaço e são, portanto, fonte de conflitos que me permitirei abordar nesta reflexão ao comparar lógicas de apropriação espacial. Elas podem ser compreendidas desde as perspectivas do habitar e do lazer e se distinguem pela sintaxe espacial produzida, de modo que a primeira corresponde ao caminho e, a segunda, à trilha. Descreverei então duas formas de se vivenciar a paisagem no caso de Vargem Grande, que não necessariamente se excluem, mas que, institucionalizadas sob certas políticas de manejo do PEPB, polarizam perspectivas nativas e não nativas de entendimento e percepção ambiental.

Não argumento que uma percepção seja mais autêntica que a outra, mas, baseando-me em trabalho de campo junto a agricultores do quilombo da Vargem Grande, privilegio aqui o ponto de vista nativo. Já a análise das perspectivas do lazer origina-se, em parte, da revisão e leitura de manuais e guias de trilhas, de onde é possível inferir categorias próprias que descortinam formas de relacionamento e entendimento com o dito mundo "natural".

O presente entendimento da perspectiva do habitar remete à análise da relação entre paisagem e parentesco explorada alhures (RODRÍGUEZ, 2016), quando me vali do olhar etnográfico durante uma temporada de seis meses de trabalho de campo, em que morei na casa do agricultor Pedro Mesquita e o acompanhei em suas incursões diárias pelos caminhos do lugar. Também realizei entrevistas e conversas com outros membros da família Santos Mesquita, assim como com outros moradores de Cafundá e Morro Redondo. Outra parte das informações aqui apresentadas é produto de minha participação pessoal em vários encontros de divulgação e debate em torno do projeto Trilha Transcarioca.

A etnografia se iniciou em 2014, um mês após a comunidade receber a certidão de reconhecimento como remanescente de quilombo por parte da Fundação Cultural Palmares (FCP), e num contexto de organização comunitária em prol do pedido de demarcação territorial ante o Instituto 
Nacional de Colonização e Reforma Agrária (INCRA). A motivação dessa demanda surgiu, em parte, como forma de contestar atropelos e arbitrariedades cometidos pelos administradores do Parque Estadual da Pedra Branca (PEPB). Meu trabalho etnográfico se centrou nas famílias que organizaram o Quilombo da Vargem Grande e, ainda que nem todas se dediquem à agricultura e muitos tenham incursionado em trabalhos urbanos, a percepção dos habitantes da paisagem continua atrelada às memórias do parentesco.

\section{A Perspectiva do Habitar}

O habitar não se refere simplesmente ao fato de se possuir uma residência. Traduz-se, segundo Heidegger (2002), no modo como o homem, ao se relacionar com as suas possibilidades de ser no mundo, constrói o mundo que o circunda. Sendo assim, teríamos que só é possível habitar aquilo que se constrói. Em outras palavras, o mundo não se apresenta a um sujeito como o espaço que contém uma coleção de coisas, mas como lugar ao qual se está ligado por uma relação de pertencimento. Habitar é ser trazido à paz de um abrigo.

O traço fundamental do habitar é esse resguardo. O resguardo perpassa o habitar em toda a sua amplitude. Mostra-se tão logo nos dispomos a pensar que ser homem consiste em habitar e, isso, no sentido de um de-morar-se dos mortais sobre essa terra. Sobre essa terra" já diz, no entanto, "sob o céu". Ambos supõem conjuntamente "permanecer diante dos deuses" e isso "em pertencendo à comunidade dos homens". Os quatro: terra e céu, os divinos e os mortais, pertencem um ao outro numa unidade originária (HEIDEGGER, 2002; p.3)

Demorar-se junto às coisas é permitir que elas aconteçam em seu vigor, o "demorar-se" está relacionado à paisagem, que materializa a realização desse encontro. O demorar-se, afirma Heidegger, acontece "nos lugares que dão moradia à demora dos homens" (2002; p.8). Desta forma, o tempo entra como variável para falar de permanências, da espera encarada na construção das casas, da paciência para acompanhar a germinação e a safra do plantado, do aguardo na gestação e criação dos filhos, dos mutirões organizados para compor caminhos e estradas, entre outros fluxos que compõem a vida. 
Mesmo sem conter noções mais simétricas sobre as relações homemnatureza, os termos de Heidegger permitem-nos uma aproximação à relação que os agricultores da Vargem Grande têm estabelecido com o maciço da Pedra Branca, onde a noção de "demorar-se junto às coisas" assemelha-se ao dizer nativo sempre estivemos aqui, um dizer que abrange as dimensões familiares e sociais, produtivas e espirituais dos atuais moradores da vertente de Vargem Grande do PEPB (RODRIGUEZ, 2016).

Alguns desses aspetos essenciais, que serão abordados a seguir, na análise sobre a produção agrícola e os caminhos, conformam um conjunto de condições que permitem que falemos hoje de uma paisagem entendida como a própria condição de ser no mundo, em que cultura, natureza e sujeito estão entrelaçados. Deste modo, a paisagem não é um cenário no qual que se inscrevem as relações sociais, nem um elemento externo às relações, mas ela própria constitui e é constituída simultaneamente pelas relações de todos aqueles que a habitam: homens, plantas e animais (INGOLD, 2000).

Ao privilegiar o ponto de vista dos agricultores do maciço, torna-se indispensável abordar o cultivo de banana, caqui e hortaliças. Mais que um traço produtivo e identitário dos habitantes, essa atividade é uma tarefa de íntimo relacionamento com o ambiente. Considerando a perspectiva do habitar, a agricultura está imbrincada às cosmologias e conhecimentos locais de fluxos e ritmos sazonais.

A cultura da banana e caqui no maciço inclui grande variedade de espécies, cada uma das quais se desenvolve em condições ambientais precisas, o que não deixa de lado a contínua experimentação de técnicas e introdução de espécies não nativas. Contudo, a vontade e o trabalho do agricultor não são suficientes para que uma muda vingue. A "vontade" das plantas também conta, pois, como afirma Pedro Mesquita, "elas escolhem dar ou não, às vezes você faz de tudo para o caqui dar certo e de repente vem as formigas e aí já não dá para fazer mais nada". Assim, os devires não humanos intervêm permanentemente nos projetos humanos.

Puxar banana é o momento em que se faz coleta. Ela acontece toda semana, são investidos de 2 a 4 dias, dependendo do número de roças, da participação agendada em mercados urbanos e da própria produção ao longo do ano, que varia de semana para semana e de estação para estação.

Para o observador inadvertido, a coleta da banana parece aleatória, mas na verdade é precedida de uma complexa sistematização, produzida nas visitas frequentes dos agricultores a cada uma das roças que podem vir a ter. Durante essas incursões, o agricultor executa várias atividades conjuntas: 
umas que fomentam as condições para o crescimento das plantas, tais como abonar e roçar as mudas; e outras conexas, como "limpar caminho", recolher capim para os burros e coletar outros elementos, como frutas de temporada, lenha e ervas medicinais. Como um tipo de perspectiva invertida, podemos deixar de ver plantas e animais como um conjunto de elementos passivos do meio natural ao serviço dos seres humanos, para começar a pensar os humanos e suas atividades como parte do ambiente das plantas e os animais (INGOLD, 2000; 2011).

À medida que essas atividades são executadas, o agricultor faz uma varredura visual: enquanto caminha, está atento ao crescimento e grau de maduração dos cachos de banana, o que lhe ajuda a decidir em quantos dias deve voltar para pegar a banana no ponto certo. É o deveja que lhe permite estocá-la até o dia da comercialização: nem muito verde ao ponto de não amadurecer, nem muito madura ao ponto de amassar durante o transporte. Esse ponto de decisão do momento em que se coleta a banana associa o conhecimento ao movimento, tornando-o um conhecimento performativo, formado entre as idas e vindas dos agricultores pelos caminhos do maciço. Se conhece porque se caminha. Daí que a epistemologia espacial nativa admita uma série de elementos advindos da comunhão com as coisas e do demorar-se junto a elas permitindo a emergência de categorias sensíveis (LEVI STRAUSS, 1976).

Os sítios de um agricultor limitam com os de outro, e a forma mais comum de estabelecer limites entre roças de diferentes proprietários é mediante o traço de prumos, feitos com castanheiras, árvores que se erguem retas como postes e são plantadas a uma distância que permite a visualização da árvore seguinte. Todos conhecem bem os limites de propriedade que estabelecem os prumos; identificar a área que as castanheiras demarcam é fundamental para evitar conflitos entre proprietários. Uma palmeira menor, chamada coqueirinho, também é usada para fazer marcações e cercas; nas casas também cultivos de flores e jardineiras demarcam o espaço doméstico do espaço mais público. Nos tempos em que a umbanda era mais difundida, a casa de um macumbeiro se reconhecia porque na sua entrada havia plantas conhecidas como espada de São Jorge, arruda e comigo ninguém pode.

Deste modo, as árvores e plantas não são apenas elementos da natureza, mas também essencialmente marcadores espaciais, atestado e símbolo da presença humana no lugar. As árvores testemunham histórias de residência e lavouras passadas e atuais. Assim, nas percepções do espaço e do tempo, os elementos da natureza cumprem o papel de fontes documentais e coloca no 
patamar dos projetos humanos os devires não humanos (INGOLD, 2000). Essa dialética, implicada no conceito de paisagem como engajamento no mundo, indica uma radical assunção da simetria e do pertencimento dos seres humanos e não humanos à terra, bem como de uma consequente agência do ambiente e dos não humanos nos projetos humanos (LATOUR, 2008).

Além da agência da castanheira, do coqueiro, dos canteiros de flores e das ruínas na documentação das práticas sociais, estão também os relatos no papel da demarcação territorial, pois as operações de demarcação são também contratos narrativos compostos de fragmentos de histórias anteriores que se articulam de um modo único, para fundar lugares. Traçar as fronteiras é parte de fazer a genealogia do lugar (DE CERTEAU, 2013), mas nem tanto por uma preocupação histórica, como pelo estabelecimento de uma ordem no mundo vivido.

\section{Os Caminhos}

Os caminhos na paisagem do maciço não têm apenas desempenhado estruturalmente a intermediação entre o rural e o urbano dada na produção agrícola e o comércio em feiras urbanas, eles também participam da organização das relações sociais, fazendo parte da série de denominações de localidades -núcleos, sítios e caminhos - e da série de denominações de família/ parentesco, em que a identificação de uma localidade e um nome de família insinuam um processo de "localização" das famílias e de "familiarização" das localidades. Assim, os caminhos mediam relações entre categorias cruciais, como o público e o doméstico, o trabalho e o descanso, os vivos e os mortos, e os deuses e os homens, adquirindo por esse viés o status de fato social total ${ }^{2}$.

Mal se pode falar da ocupação do maciço da Pedra Branca sem se fazer referência à função que os caminhos cumpriram na colonização histórica e atual desse espaço, assim como no estabelecimento de rotas comerciais. Sabe-se que, à medida que os diversos ciclos econômicos (cana, carvão,

\footnotetext{
${ }^{2} \mathrm{O}$ "fato social total" foi concebido por Mauss em "O ensaio sobre a dádiva" (1924) para designar fenômenos sociais complexos que abrangeriam interpretações provenientes de diversas áreas do conhecimento, interdisciplinarmente.
} 
café) avançavam pelas encostas, a abertura de caminhos no interior da mata era requisitada; além disso, esses caminhos aproximavam lugares como Camorim, Rio da Prata, Pau da Fome e as Vargens. Alguns dos antigos caminhos coloniais mantêm seus calçamentos de pedra visíveis e continuam presentes no cotidiano e nos relatos dos habitantes.

Referências espaciais imprescindíveis, os caminhos são outra forma de nomear a paisagem que nunca ficam à margem de ricas e densas narrativas. Ligados a diferentes dimensões da vida social, os caminhos mobilizam a memória e sempre contam histórias para quem tem uma pergunta; evocam cheiros, sabores e lembranças; trazem para o presente fragmentos de passado e atualizam as tramas do parentesco e da vizinhança. As atitudes que se estabelecem com a natureza e o local reforçam certo tipo de união, em que os espaços são definidos mais pela ocorrência de atividades e relações entre parentes do que pela sua localização num espaço abstrato. Desse modo, o espaço físico e as suas propriedades não estão separados das experiências que o contêm.

Desde o caminho, a paisagem descortina uma história do lugar escrita nos processos vivenciados pelos moradores da serra. Cada ponto e lugar tem suas próprias entrelinhas, configurando uma epistemologia espacial nativa não redutível a nenhuma cartografia científica cartesiana ou apenas a um zoneamento ambiental.

Há caminhos com nomes fixos, sendo referência coletiva imutável (Caminho do Cafundá, Caminho do Morro Redondo, Caminho do Morgado, Caminho do Mato Alto). Quando o caminho chega à cidade formal, descaminha-se para se oficializar, congela-se para perder seu caráter provincial, adquirindo o status de estrada com a inalterabilidade ligada ao CEP. As estradas de Cabungui, Serra Dourada, Mucuíba, Pacuí, entre outras, foram alguma vez um estreito caminho aberto, melhorado pelo esforço dos próprios habitantes. O contrário também acontece: verdadeiras estradas, ao perderem usuários, tornaram-se caminhos; alguns deles somem, deixando rastro apenas na memória nativa.

Em contraste, a toponímia dos caminhos se mostra mais flexível, dependendo do narrador, de sua idade, do envolvimento de sua trajetória pessoal com lugares, parentes e vizinhos, antigos ou atuais. É a forma como os caminhos se atualizam, tornando-se, de certa forma, distintas versões de si mesmos, dependendo às vezes da direção, de onde se começa o trajeto, ou para onde se vai. No asfalto, o caminho do Cafundá é a continuação da estrada Mucuiba, mas, quando passa pelo núcleo de casa Juarez, pode se 
chamar caminho de Juarez (Juarez e seus genros trabalharam nesse trajeto). Continuando para cima, o caminho adquire o nome de Cano de Ferro, por causa de uma nascente de água que foi canalizada mediante um cano; depois disso, é indiscutivelmente o caminho do Cafundá. E, para continuar com o exemplo, seguindo pelo caminho do Cafundá, pode-se virar pelo caminho da Dormideira, que mais adiante será o caminho de Gabriel, que depois vai se encontrar com o caminho da Água Fria.

Assim, existem nomes de caminhos que fazem sentido para alguns, existem caminhos sem nome para outros e caminhos com mais de um nome. A lista é infindável: Caminho do finado Ramiro, Caminho da Dormideira, Caminho de Gabriel, Caminho do Zé Almerindo, Caminho de Manuel Paez, Caminho do Rolador, Caminho da Água Fria, Caminho de Bela Vista, Caminho do chuveiro, o Caminho de Manuel Paez: o importante é saber que os caminhos sempre guardam uma história e seus nomes remetem a acontecimentos locais.

O caminho que vai para Pau da Fome se inicia pelo Poço do Nicanor. O tio Nicanor, cansado depois de ter levado seus produtos à feira, voltava da cidade e decidiu entrar no poço para se refrescar, mas começou se afogar e só saiu vivo do impasse porque o compadre Celso o resgatou das águas. A partir daí, todo mundo começou a chamar esse lugar pelo nome do salvado. Mais adiante, encontramos o Poço da Laje, antigo lugar das delicias da moçada local, cuja pedra lisa dá a sensação de se estar numa laje; um pouco mais acima está o poço da Mãe d'água, assim conhecido pela presença de uma encantada temida por muitos. O único que não tinha medo era o avô Celso, que tinha aquele local como predileto para a caça de paca. Ali, as pacas fugiam ao mergulhar embaixo da laje, porém Celso encarava o nado e, também mergulhando, saía do outro lado fazendo das pacas presas fáceis.

Os caminhos são a materialização das narrativas familiares e das redes de parentesco. Há os caminhos que se inauguram com o início de uma relação. Antes de Pingo namorar a mãe de seus filhos, Maria, não existia um caminho ligando as casas onde cada um morava. Maria morava na casa de Dorvalino, irmão de Carmélio que conta:

Não tinha aquela estrada que sobe ali depois da ponte, não. Era o caminho do Pingo, por aquele cruzamento que tem um cano até lá embaixo naquela lama que subia para cá para subir do outro lado. Mas Pingo, de tanto ir namorar por ali, fez um trilhozinho dentro do mato. E foi passando, foi passando e foi enlarguecendo o trilho, agora é estrada. E o caminho de baixo é aquele que tinha em frente do sítio dos Vieira fechou, acabou. 
Deste modo, o começo do namoro foi também o inicio de uma rota para permitir seus encontros. O caminho é a materialização de um eterno envolvimento afetivo com a paisagem, enuncia usos de espaço, fala de lugares visitados e revisitados pela memória, pois permite produzir trajetos que descortinam cursos de vida. No seu percurso, o caminho se cruza com outros. Um encontro de caminhos chama-se estação: mais que a possibilidade de escolha de uma direção, uma estação é também o encontro retórico de duas ou mais histórias, e é assim como as encruzilhadas multiplicam retóricas.

Os caminhos nunca são passivos a trânsitos e pisadas, eles são verdadeiros agentes na paisagem, dispõem do tempo dos homens e os organiza em prol da sua manutenção, devendo ser feitos e refeitos. Os caminhos penosos desgastam as ferraduras dos burros e causam estragos nos carros, dificultam o transporte dos produtos da roça, limitam a expansão da agricultura, embaraçam a chegada à escola e atrapalham a vida do doente e do idoso. Ao estarem imersos em processos vitais (INGOLD, 2000; 2011), os caminhos nunca estão prontos, nunca permanecem imóveis, eles exigem de seus usuários os esforços contínuos de roçado e manutenção.

O caminho não é estático: uma enchente empurra pedras e barreiras clausurando o trânsito; em consequência, caminhos principais são abandonados, forçando a procura de alternativas, atalhos que, com o tempo, tornam-se principais. O caminho é uma luta constante na qual o mato sempre ameaça vencer, a falta de uso o fechar, obrigando a desbravá-lo constantemente; a chuva o atola e a árvore, caída, ou cria atalhos ou mobiliza as pessoas para retirá-la. Já o atalho mostra o essencial, que é saber o caminho alternativo, aquele menos transitado e oculto que persiste à insistência do mato.

O caminho não é uma intervenção na paisagem, ele próprio é a paisagem, somatória dos esforços humanos e não humanos; pois, como indica Ingold (2000), a paisagem é construída na interação entre projetos humanos e devires humanos e não humanos.

Temos concordado com Ingold (2000), quando afirma que corpo e paisagem se geram a si mesmos de forma simultânea e mútua, deixando de lado a ideia de paisagem como pano de fundo em que a ação acontece para ser, ela mesma, um feixe de ações articuladoras do encontro humano e não humano, produzindo de tal encontro uma mútua inscrição das marcas humanas no ambiente e deste na experiência humana do mundo. Se os caminhos representam uma parte dessa inscrição, os mesmos têm deixado suas marcas na experiência humana que os produz. 
Falar dos caminhos é narrar empreitadas e mutirões feitos entre parentes e vizinhos que os tornam possíveis. Feitos na mão ou na enxada, os caminhos são ajeitados, empedrados e cimentados com recursos próprios e ferramentas básicas. A partir do momento em que o burro deixou de ser o único meio de transporte de acesso às íngremes encostas e começou a partilhar funções com motos e carros, foi necessária a adequação dos caminhos às rodas.

O registro das empreitadas é o próprio caminho ou, às vezes, eventos significativos como casamentos ou aniversários que exigiram seu conserto. Nem sempre todos os usuários têm consciência do trabalho investido, ou dos arranjos feitos que permitiram que hoje um trajeto seja transitável. Placas com nomes dos caminhos não são usuais: os agricultores não precisam delas para ler a paisagem.

Ao pensar no traçado e construção de caminhos, podemos raciocinar com Heidegger (2002) na capacidade de "um deixar-habitar", tornar habitável um lugar, pois somente em sendo capazes de habitar é que se pode construir. Construir caminhos é edificar lugares, permitir usos e acessos; caminhar é fundar e articular espaços.

\section{Polifonias do Lazer}

A presença de visitantes no maciço não representa nenhuma novidade para os habitantes de Cafundá e Morro Redondo. Do ponto de vista nativo, visitantes sempre foram bem-vindos e fazem parte do universo de relações que constituem a paisagem. De fato, se Magalhães Correa concedeu nas suas reflexões algumas linhas ao turismo, sua apreciação não deixa por fora o contraste existente entre as atividades dos habitantes e o agir dos turistas, contraste que, como veremos, continua ainda a se manifestar.

Ao longo da estrada, transformada em feira livre, pelos seus habitantes, encontram-se gurys, à margem de suas choupanas, tendo em permanente exposição gaiolas com passarinhos, meninas vendendo ovos e galinhas, mulheres e velhos com bananas e laranjas, em fim tudo que produz essa zona exuberante Estas mercadorias em vários giráos e ganchos, esperam a passagem dos turistas, que infelizmente só são estrangeiros, pois os pois os nossos, quando vão por essas estradas, passam em automóveis voando, já são conhecidos; quando chegam, porém, aos lares ou em roda de amigos, dizem: 'foi extraordinário, indescritível o que 
vimos!...Pobres dos que ficaram no caminho, pois à sua passagem transformam a estrada em verdadeiro vendaval, nuvens de poeira, só poeira! sic (MAGALHÃES CORREA, 1936; p.59)

A beleza cênica do maciço da Pedra Branca sempre atraiu turistas, e os habitantes foram não só se acostumando, como também classificando essas formas do lazer urbano: o pessoal da cachoeira, os cavaleiros e os motoqueiros, e até mesmo se preparando para seu recebimento, providenciando-lhes informações e vendendo-lhes comidas e bebidas ${ }^{3}$. Esses atos do lazer atingem diferentes definições de acordo com a relação que os próprios grupos estabelecem com o lugar e as atividades realizadas. Para os moradores locais, esses atos de lazer englobam práticas de caráter temporal realizadas por pessoas de fora da comunidade e que rendem um tipo de renda. Já os ambientalistas recorrem a uma classificação das atividades que pondera os impactos erosivos dessas atividades no solo ou as possibilidades de aliança nas metas da preservação. Daí as distinções entre "bons" e "maus" usuários que serão exploradas mais adiante.

No verão, os passeios ao local atingem um pico. Sem se reduzir a essa estação, os visitantes que, na sua maioria, são moradores da cidade, e em particular da zona oeste, realizam incursões curtas que não passam de uma jornada: manhã, tarde ou noite. Essas visitas promovem a concentração de esforços dos proprietários de pequenos bares e vendas de comida nesses períodos e a mobilização de alguns trabalhadores locais para empregos sazonais nos clubes campestres existentes em Vargem Grande.

Esses passeios à serra ainda não representam uma mudança no modo de vida local nem comportam, todavia, nenhuma das três dimensões consideradas como o tripé da indústria do turismo, a saber, transportes, hospedagem e agenciamento (BARRETTO, 2003). Porém, a publicidade que o lugar vem recebendo deixa apreensivos alguns moradores que têm sentimentos ambíguos frente ao incremento de visitantes. Ainda que o pequeno comércio obtenha ganhos econômicos, espaços domésticos e de plantio são invadidos; motoqueiros danificam caminhos, abrindo valas; e banhistas e caminhantes se aventuram dentro de propriedades particulares.

\footnotetext{
${ }^{3}$ As minhas observações sobre a relação entre os moradores, o parque, as trilhas e os visitantes em Cafundá e Morro Redondo não são extensíveis para todas as comunidades do maciço da Pedra Branca.
} 
A presença massiva de pessoas de fora inibe a visitação de nativos a poços e cachoeiras, sempre lotados; e, para muitos, a divulgação das trilhas é contraproducente, pois o aumento do fluxo de pessoas é sinônimo de um incremento no lixo para o qual o serviço de coleta é precário, quando não inexistente (CARVALHO, 2015).

O verão traz uma dose diária de banhistas que espalham sua presença ao longo da estação. Com o final da temporada, a presença de banhistas se reduz a finais de semana mais calorentos. As cavalgadas acontecem em qualquer época do ano e, inclusive, em horário noturno, enquanto os motoqueiros preferem frequentar o lugar nos finais de semana. Também fazem parte das perspectivas do lazer as dezenas de casas de veraneio construídas dentro do parque e suas imediações sem ser habitadas de forma permanente, mas visitadas em feriados e finais de semana.

Um marco importante para pensar o lazer e o ócio é dado pela sua oposição ao mundo do trabalho nos patamares da assunção capitalista ${ }^{4}$. Nesse sentido, férias e finais de semana marcam a temporalidade do lazer para as pessoas da cidade, que de certa forma difere da noção heideggeriana do demorar-se junto às coisas. Na definição do lazer, a oposição urbano/rural configura-se necessária para abordarmos a idealização dos parques naturais como modelo de área protegida associada a valores estéticos e lúdicos alimentados por poderosas fantasias de naturezas desabitadas.

A possibilidade de interação com a "natureza" e a busca pelo sossego correspondem a um conjunto de representações características de populações urbanas sobre o dito "natural", concebido como o espaço privilegiado para a harmonização da vida cotidiana, e não mais como o manancial de recursos para uso humano, expandindo sensibilidades relacionadas ao meio ambiente (STEIL; TONIOL, 2011). Nesse sentido, visitar um parque aparece como

\footnotetext{
${ }^{4}$ A conquista de tempo para uso livre nos remete aos primórdios da Revolução Industrial, quando era comum os trabalhadores se entregarem a tarefas infindáveis, até ficar exaustos. O capitalismo nascente, descreve Magnani (2000), exerceu um disciplinamento do tempo, marginando da racionalização do tempo as marcações dadas pelos ciclos da natureza ou os calendários religiosos e festivos que ditaram no período pré-industrial o ritmo do trabalho. Com sua produção virada para o mercado, a conservação e a reposição da força de trabalho dependeram em principio do seu próprio trabalhador, que devia arcar com os custos dessa reprodução, mediante alimentos, descanso, teto e cuidados médicos. Melhores condições de trabalho e vida, como diminuição da jornada, descanso semanal remunerado e férias foram uma das maiores conquistas da classe trabalhadora, o que é um paradoxo, pois esse tempo livre é para manter e reproduzir essa força.
} 
a possibilidade de fuga da cidade. Isso pode explicar, parcialmente, certas reações de moradores urbanos frente a ameaças, reais ou potenciais, de degradação da natureza ou da privatização de um espaço que deve conservarse disponível ao usufruto de toda a população (FERNANDEZ, 2009).

\section{A trilha}

O acesso a esse ideal de "natureza" se dá através das trilhas. Ainda que a trilha constitua o próprio fim como atividade de lazer, ela também representa, para alguns habitantes urbanos, a mediação entre a cidade e a natureza, o trabalho e o lazer, a tranquilidade e a agitação, a monotonia e a aventura. Ao procurar por definições de trilha, encontra-se uma certa variabilidade, porém as palavras lazer, parque e ecoturismo aparecem com frequência.

As trilhas são a principal infraestrutura de manejo de visitantes em áreas de apelo ecoturístico e as unidades de conservação públicas são o grande destino dos milhares de visitantes, que buscam os ambientes naturais para lazer e prática de esportes (DA COSTA, 2006; p.6).

A trilha é um caminho estreito, normalmente não transitável por automóvel, sendo um corredor linear, na terra ou na água, com status de proteção e acesso público para recreação ou transporte (MENEZES 1998; p.12).

As trilhas são caminhos existentes ou estabelecidos, com diferentes formas, comprimentos ou larguras, que possuam o objetivo de aproximar o visitante ao ambiente natural, ou conduzi-lo a um atrativo específico possibilitando seu entretenimento e educação a traves de sinalizações ou recursos interpretativos (SALVATI 2003; p.01).

A trilha constitui-se um novo meio de contato com a natureza. Com a crescente urbanização tornou-se crescente a demanda por espaços naturais para o descanso mental e exercício físico (ANDRADE 2005; p.15).

Outras ideias que aparecem ao lado da trilha emolduram uma certa racionalização espacial que inclui termos como planejamento, recursos humanos, planos de manejo, monitoramento, infraestrutura e sinalização. Como analisado por De Certeau, (2013), é a capacidade de abstração, ou 
seja, de separar as coisas dos espaços, que concebe o planejamento. Assim, a presença de placas de sinalização indicando nomes, direções, distâncias, altura, presença de serviços, recados de preservação e informações sobre espécies de árvores e animais da região são desejáveis, pois sugerem ao visitante o reconhecimento do espaço como um lugar controlado, planejado e monitorado, conectado com uma certa supermodernidade, em que o mapa da viagem sempre é externo à mente (AUGÉ, 2009).

A indicação de direções, sentidos, pontos cardeais não só estão presentes na sinalização de trilhas, mas também aparecem nas narrativas contidas nos manuais de caminhada pelo parque, cujas descrições técnicas enunciam itinerários com direções para atingir um destino, com as precisões e condições que requerem os espaços de circulação. Deste modo, a mediação que estabelece o vínculo das pessoas com as trilhas passa por palavras e textos que propõem modos de uso e, parafraseando Augé (2009), formas prescritivas (- tomar a bifurcação da direita), proibitivas (- proibido alimentar os animais) ou informativas (- Você está aqui), que recorrem a ideogramas codificados por consenso.

Voltando até a trilha principal, seguindo dessa vez para a direita na última bifurcação, com menos de cinco minutos de caminhada chega-se em outra entrada à esquerda, que dá acesso, por uma curta caminhada, a outro poço com uma pequena queda d'água e fundo de areia. Voltando à caminhada pela trilha principal, sem entrar em qualquer bifurcação, sempre no sentido nordeste, em cerca de 1,5 km cruza-se um riacho e logo depois chega-se em um bananal, onde a trilha fica bem confusa. Siga até quase o final do bananal, onde poderá seguir por dois caminhos. O primeiro é entrando à esquerda, sentido norte, alcançando a escondida Cachoeira Encontro dos Rios, em poucos minutos por uma trilha mal marcada. O outro caminho é entrando à direita, sentido nordeste, iniciando a subida do Vale do Gunza. Existe no início do bananal um caminho, também à direita, mas é um pouco mais fechado, que passa primeiro por uma gruta, e depois se encontra com a trilha que sobe o Vale do Gunza em definitivo. Caso queira apenas visitar as belas cachoeiras e poços, esse bananal é o ponto final da caminhada. Volte pelo mesmo caminho (INEIA, 2013; p.240).

Esse tipo de descrição técnica, cheia de detalhes de natureza física e biológica produzida pela observação e, às vezes, pelo georreferenciamento, é comum nos manuais de trilhas, que oferecem roteiros de cuidados e 
descritores tipo mapa, correspondentes a um tipo de abstração moderna desprovida das histórias e toponímias locais e das experiências e práticas que produziram esse espaço (DE CERTEAU, 2013). Trata-se da mesma lógica que permite a delimitação de fronteiras claras e precisas, possível quando uma sociedade possui estrutura tecnológica e geométrica para representar um espaço independente de eventos. O mapa que acompanha os manuais de trilhas é parte de uma abstração isotrópica espacial, cuja intenção de se tornar universal e acessível para qualquer caminhante precisa da autonomia do relato local.

A trilha tem como propósito servir aos caminhantes, porém outras modalidades de recreação praticadas, tais como cavalgada, motocross e pedaladas, terminam por compor um leque de polifonias do lazer que nos afasta da imagem de grupos mais ou menos homogêneos, com olhares e sensibilidades ecológicas que se deslocam em uma mesma direção, tanto objetiva como simbolicamente.

Ao nos focar nas práticas do lazer praticadas no PEPB, encontramos, na verdade, uma arena de disputas que abriga tensões e conflitos entre diferentes discursos, enunciados, sentidos e representações de natureza, que colocam em relevo, entre outras coisas, oposições como cotidiano e não cotidiano, trabalho e lazer, ordinário e extraordinário, em que a natureza aparece nos termos de uma promessa de ruptura com o cotidiano e com aquilo que se vivencia no dia a dia do meio urbano (STEIL; TONIOL, 2011).

Entre as práticas de recreação levadas na vertente de Vargem Grande do PEPB, encontram-se os banhos nas cachoeiras, às quais se chega mediante pequenas trilhas, que nem sempre se fazem a pé - e, desvirtuando o espírito que os ambientalistas têm imputado à trilha, os banhistas realizam uma boa parte do percurso em automóveis que, uma vez estacionados, congestionam os caminhos, impedindo às vezes a passagem dos próprios moradores.

As cavalgadas, propiciadas pela existência de haras localizadas no entorno do maciço, são também uma atividade comum em Vargem Grande. Com efeito, se o uso do cavalo já esteve associado a necessidades de transporte e comunicação entre diferentes localidades do maciço no passado, ainda hoje uns poucos moradores recorrem a ele como meio de transporte. Mas, sem sombra de dúvidas, seu uso mais generalizado se relaciona com o lazer de um segmento das classes médias. Os haras oferecem, entre algumas opções, passeios pela trilha do Morgado, ou até Rio da Prata e Campo Grande.

Cavalgar por caminhos abertos no meio de exuberante Mata Atlântica, sem ter que se preocupar com suar a camisa para atingir 
o destino final, constitui-se um prazer inesquecível. Uma vez montado em um puro sangue, sua única preocupação será admirar as belas vistas que se descortinam das trilhas, ora Vargem Grande do alto do Morro, ora a baixada de Guaratiba, ora o mar longínquo, ora um simpático açude. Se você já tem alguma experiência hípica, estes passeios vão surpreendê-lo (MENEZES, 1998; p.163).

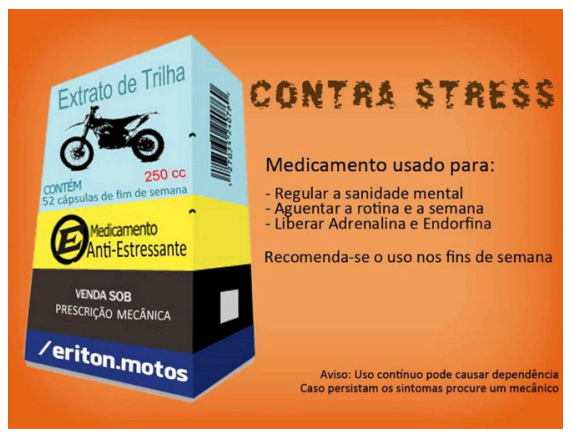

Figura 1 - Charge promocional de curso de motocross achada numa página de Facebook

Fonte: https://www.facebook.com/ pages/Maromba-Racing-Curso-deMotocross/348138888561151
A travessia de trilhas mediante veículos como bicicletas e motos também é comum. O bicicross e o motocross são esportes que cada vez mais atraem novos usuários para as trilhas do parque, que ali se encontram para praticar treinos e competições. Os encontros são filmados, e os vídeos são postados na internet. A presença dos motoqueiros é das mais problemáticas para os habitantes, tanto pelo barulho como pelo perigo associado à alta velocidade, potencial causadora de acidentes.

A maioria dos visitantes reconhece o caráter público do parque, mas nem sempre é dada a reconhecê-lo também como um espaço de moradia: daí a ousadia de pegar bananas e plantas como dádivas da natureza para seu desfrute e transitar por ele como um espaço sem donos. As principais queixas dos moradores se relacionam com o lixo deixado pelos banhistas e caminhantes e com as motos de carreira e em competição, cuja passagem em alta velocidade causa acidentes e deteriora os caminhos habituais, inutilizando-os para os moradores e até para os mesmos motoqueiros e, assim, motivando a abertura de novos atalhos. Em dias de chuva, o dano é pior: os burros se atolam e pessoas e carros não conseguem passar. O passo dos motoqueiros por Cafundá e Morro Redondo atualiza a descrição que Magalhães Correa (1934) fizera uma vez em respeito aos turistas de outrora, que só deixam poeira e lixo! Uma imagem, encontrada em uma dessas páginas (Figura 1), ilustra o espírito do motocross, suas conexões com estados anímicos, com a aventura e a tecnologia.

A metamorfose de caminhos em trilhas obedece tanto à transformação do maciço em parque como à implantação de uma política pública de manejo que vem sendo testada e construída. Dita proposta de intervenção 
é enunciada, no entanto, sem estrutura e recursos humanos suficientes, minando a capacidade de controle e monitoramento que uma intensa visitação demanda. O resultado termina sendo uma incongruência, chega-se à destruição do objeto de preservação. Daí que o turismo como estratégia de preservação ambiental carregue consigo para uma certa inconsistência (LORENZO, 1996 apud MANHÃES, 2003).

Em síntese, as características dos usuários das trilhas são variáveis e relativas e impõem como desafio mais que uma denúncia ou demonização dessas práticas, a necessidade de se compreender as relações que pessoas, individualmente ou em grupos, estabelecem com a "natureza" e os ambientes visitados. Que tipo de experiência é essa? Que tipo de natureza é procurada em cada uma dessas práticas? Por que são toleradas pelo parque? Sem sombra de dúvida, nos faltam estudos e etnografias que investiguem os perfis dos diferentes grupos que vivenciam as trilhas como espaços de socialização e lugares repletos de aventuras ${ }^{5}$.

Por enquanto, aqui só analisarei a arte da caminhada, vista com uma atividade planejada, desejada e estimulada pelos órgãos ambientais. A partir do livro "Transcarioca Todos os Passos de um Sonho" e do texto bilíngue (inglês/português) "Trilhas - Parque Estadual da Pedra Branca / Trails Pedra Branca State Park", são inferidas algumas categorias, entendimentos sobre lazer e percepções de natureza. Este recorte não tem a ambição de dar conta da infinidade de experiências e grupos de montanhistas e caminhantes do PEPB.

O manejo e a implantação de trilhas aparecem explicitamente no manual do Instituto Estadual de Ambiente (INEA) "Trilhas - Parque Estadual da Pedra Branca / Trails - Pedra Branca State Park", e são reafirmados com a implantação da Trilha Transcarioca. Na apresentação do manual, lê-se, logo nas primeiras páginas, que dentro dos limites do parque

(...) podem ser realizadas atividades recreativas em contato com a natureza; educativas e interpretativas; pesquisas científicas; ecoturismo e esportes e turismo de aventura (...) A revitalização do

\footnotetext{
${ }^{5}$ Por outro lado, estamos diante de uma complexa trama de interesses, motivações, sentimentos e sensações experimentadas no uso das trilhas junto à "natureza", que se articula a pequenas e grandes empresas (empresas de ecoturismo, haras, veterinárias, lojas de motocicletas) e serviços como de oficinas mecânicas, comércio de roupas especiais e acessórios, etc., assim como de mapeamento de trilhas, geração e distribuição de informações das mesmas.
} 
Parque Estadual da Pedra Branca começou a se concretizar a partir de 2001 com a aplicação da Lei 9.985/2000, que instituiu o Sistema Nacional das Unidades de Conservação - SNUC. Vários projetos estão em andamento visando proteger a sua biodiversidade, propiciando à população local e aos visitantes um agradável ambiente de lazer em pleno contato com a natureza (2013; p.27). negrito meu.

Ao fazer uma reconstrução da evolução das trilhas do parque, os organizadores do livro destacam seu vínculo com os ciclos de exploração econômica que marcaram o desenvolvimento da cidade. Em seguida, afirmam que, no século XX, o crescimento populacional provocou a aceleração da ocupação das encostas. Deste modo, a floresta passou a viver uma nova fase de degradação a partir de uma refuncionalização dos antigos caminhos do Maciço da Pedra Branca, que se tornaram veículo de degradação ambiental.

A apresentação do manual termina dizendo que esse novo ciclo foi felizmente combatido mediante a criação do parque onde "as trilhas passam, então, a ter a mais importante função de toda a sua história: a de veículo de conservação/preservação ambiental e de uso público "destinadas ao lazer e ao ecoturismo" (2013; p.84). É importante ressaltar que é a partir dessa política que as palavras turismo e ecoturismo aparecem na linguagem dos gestores do PEPB e que nem visitantes locais, nem a população anfitrioa apelam até o momento para a noção de turismo. É com a Transcarioca que questões como hospedagem, logística e agenciamento, visando a um turismo global especializado, aparecem no contexto do manejo do PEPB.

No bojo das transformações promovidas pelo turismo, Urry (2001) identifica uma mudança no olhar do turista que deixa de ter um certo ar romantizado e individual para um olhar mais sóbrio e coletivo. Esse tipo de olhar coletivo se caracteriza pela onipresença, muitas vezes institucionalizada, de filtros e modos de percepção que sobrecarregam com valores próprios qualquer tipo de paisagem. Esse olhar se constrói na presença de um número significativo de pessoas, que é o que garante o sucesso de tais lugares.

\section{Tritha Transcarioca}

Com frequência os espaços turísticos de caráter natural tomam-se como realidades dadas, o caso da Trilha Transcarioca permite compreender os processos particulares que fazem emergir um lugar como destino turístico, 
os quais também são produtores de sujeitos, espaços e naturezas para um certo tipo de consumo.

É no contexto de conservação ambiental e de uso público do PEPB que a Trilha Transcarioca é proposta aos "usuários" e "amantes da natureza" como uma travessia do Rio de Janeiro por um percurso ${ }^{6}$ de aproximadamente 170 km, saindo da Barra de Guaratiba até o Morro da Urca, aos pés do Pão de Açúcar. O projeto sugere que a trilha poderá ser percorrida na sua integridade ou em seções, de acordo com o interesse, a aptidão e a disponibilidade de tempo de seus usuários. Uma parte dessa grande trilha assim como outras divulgadas nos manuais do PEPB passam pelos caminhos dos agricultores do quilombo de Vargem Grande.

O traçado da trilha foi idealizado pelo diplomata Pedro Cunha e Menezes no início dos anos 1990 e foi publicado no livro "Transcarioca: todos os passos de um sonho (2000)". Sob o lema "conhecer para conservar", o autor expõe as principais motivações de sua ideia, entre as quais aparecem: contribuir para a consolidação de um corredor ecológico entre as áreas protegidas $^{7}$, permitir o trânsito de trilheiros e caminhantes pelas florestas da Tijuca e do Maciço da Pedra Branca e funcionar como um instrumento para engajar escolas, universidades e outros grupos de interesse em torno da defesa e uso público de ambientes naturais no contexto urbano. A moldura para esses propósitos são as visitas às cachoeiras, prédios e ruínas coloniais e republicanas, a apreciação de jardins, a observação de animais, plantas e cavernas e os visuais incríveis que as alturas oferecem (MENEZES, 2000).

O projeto tem como inspiração diversos exemplos de trilhas de longo curso, tais como Huella Andina (Argentina), Hoerikwaggo Trail (África do Sul), Te Araroa Trail (Nova Zelândia), e a Appalachian Trail (EUA) ${ }^{8}$;

\footnotetext{
${ }^{6}$ O percurso que passa por seis unidades de conservação: Parque de Grumari, Parque Estadual da Pedra Branca, Parque Nacional da Tijuca e os parques naturais municipais da Catacumba, da Paisagem Carioca (Morro do Leme e Babilônia) e Morro da Urca.

${ }^{7}$ Segundo Menezes, amalgamar várias unidades de conservação aumenta a contiguidade das áreas protegidas e reduz o confinamento de espécies que produz um enfraquecimento genético (MENEZES, 2000; p.15)

${ }^{8}$ A Appalachian Trail é o modelo mais inspirador para Menezes pois seus 3600 quilômetros ininterruptos começaram por estradas de terras e propriedades privadas, sendo que a intensidade da visitação anual criou tal força política que o governo destinou orçamento para a desapropriação de terrenos ao lado da trilha e ao longo de todo o trajeto (MENEZES, 2000; p.20).
} 
a Transcarioca nasce emoldurada dentro de um modelo internacional de turismo. Seus promotores argumentam que o traçado oficial tem como propósito um incremento na visitação, melhorias na gestão das áreas protegidas, geração de emprego e renda advinda dos seus usuários ${ }^{9}$ dentro dos princípios do "desenvolvimento sustentável". Pretende-se tornar a trilha parte constitutiva de um projeto político desenvolvimentista, cujo estabelecimento proporcionaria melhorias ambientais para a cidade (IBID).

A Transcarioca ajudaria a reverter a lógica econômica vigente de que esse corredor é um entrave à expansão e ao desenvolvimento. Ter essa trilha é assegurar que os parques do Rio serão ligados por um caminho verde, que terá um grupo permanente de apoio à sua manutenção - os próprios transcarioqueros e a comunidade montanhista, cujos membros se multiplicaram muito (MENEZES 2000; p.21).

Uma ideia que permeia o texto de Menezes é que o homem e a cidade são os maiores inimigos dos parques, visão derivada do pressuposto de que estes representam simbolicamente espaços de resistência frente a um modelo de desenvolvimento econômico predatório. Dai que a estratégia pragmática de parte dos grupos ambientalistas no Brasil e no mundo seja a de preservar ilhas de vegetação nativa de um processo agressivo de crescimento urbanoindustrial considerado como inexorável.

Preocupam ao autor problemas sociais de segurança pública e crescimento das favelas, mas ele mantém a esperança de que a natureza um dia vença a cidade. Para ele, a Transcarioca procuraria tornar o homem e a cidade aliados da conservação da "natureza" a partir de um processo educativo dado pela adoção de regras e modos de comportamento, que sob meu ponto de vista não deixam de preconizar uma possibilidade de "aperfeiçoamento de si" para o montanhista convertido, e também um certo projeto civilizatório para a população local. Dito processo civilizatório do nativo, em quanto aos seus usos e práticas da natureza, não é novidade, ele subjaz na própria legislação, está presente nos órgãos de controle ambiental e na mentalidade de alguns

\footnotetext{
${ }^{9}$ No momento da publicação do livro, o autor estimou que o os gastos diários de um excursionista seriam uma média de U\$ 15 dólares por dia, mais alimentação, mapas, camiseta, equipamento e pernoite.
} 
grupos ambientalistas. O projeto da Trilha Transcarioca seria apenas a posta em marcha de um regime de regulação sócio-espacial, capaz de imaginar e transformar espaços, naturezas e sujeitos.

Através da leitura de "Transcarioca: todos os passos de um sonho" encontramos reflexões do autor sobre as relações homem/natureza, natureza/cidade, o sentido do trekking, e classificações operadas sobre os "usuários" das trilhas. O autor esclarece diferenças entre Trekking, caminhada de mais de um dia, Hiking, caminhada de menos de um dia, e Looping, caminhada circular. Em qualquer dessas modalidades sobressai a importância concedida ao sentido da visão. Menções a belvederes, mirantes panoramas deslumbrantes, vistas imperdíveis, perspectivas descortinadas e ângulos inusitados, somam-se a imaginários edênicos que além de privilegiar o olhar, prometem-se como prêmio ao caminhante que coroa um cume.

Os "usuários" das trilhas compõem um leque de categorias que deixam de lado o turista genérico para o classificar segundo seu comportamento e motivações em função de características socioeconômicas e psicossociológicas (COHEN, 1979). Assim, os usuários da Transcarioca podem ser aventureiros trilheiros caminhantes, montanhistas, andadores iniciantes, montanhistas experientes, montanhistas menos experientes ou mais preguicosos, excursionistas profissionais, malta de banhistas, excursionistas de primeira viagem e finalmente os trasncarioqueros, cujos predecessores seriam os pioneiros: aqueles que imaginaram o traçado da trilha Transcarioca e, por tal, são os sonhadores, iniciados e destemidos (MENEZES, 2000; p.25). As classificações sobre os usuários são recorrentes, divididos entre "bons visitantes" e "maus visitantes". O propósito da Transcarioca é atrair os bons.

Segundo o idealizador do projeto, montanhistas experientes temem dividir a trilha com excursionistas de primeira viagem, que não seriam gente

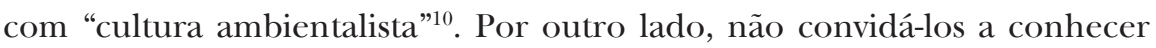

\footnotetext{
${ }^{10}$ Os seguintes trechos permitem ver a classificação operada sobre os visitantes da floresta:

"(...)Excursionistas aparentando profissionalismo, com botas e mochilas importadas, são os primeiros a entrar no mato. Junto com eles observamos os escaladores e os personagens emblemáticos da floresta, aqueles que conhecem cada pedacinho da mata, cada nascente, cada pico. (...) buscam morros de nomes pouco familiares e vales raros. Vão a São Miguel e ao Vale das Pedras. A Transcarioca para eles não tem valor, é por demais trivial. Se na trilha encontram gente, estragou-se seu passeio, prezam acima de tudo solitude, são os verdadeiros personagens da Floresta. Qual gnomos tropicais preferem ver a serem vistos." (Ibid; p.83).

"(...)Por fim, vêm os menos habitués Alguns exalam tensão, consultam mapas, procuram
} 
o ambiente que induz aos hábitos do excursionismo de mínimo impacto é perpetuar na sociedade a cultura do balão, do lixo, do esgoto não tratado, da caça e do desmatamento (MENEZES, 2000; p.71).

Da mesma forma que os caminhantes, as caminhadas também são classificadas: os manuais de trilhas operam um sistema hierárquico que categoriza as caminhadas como mais ou menos autênticas, com vistas espetaculares ou não, e mais ou menos visitadas. O grau de dificuldade e o número de adversidades do caminho impostos ao caminhante estampam nessas jornadas características de marchas heroicas. Daí que na caminhada profissional a "exaustão física" estabeleça uma diferença do lazer e do turismo convencional, levando à exaltação de valores como a dor, o esforço e a conquista (STEIL; TONIOL, 2011).

A ideia da "iniciação" atravessa a classificação dos usuários e estabelece uma mediação com os graus de dificuldade que podem ir sendo atingidos na mão de um processo de conscientização estritamente ambiental. Ao longo dos textos citados, se infere que trilhar não é uma atividade para todo mundo: depende de educação e aprimoramento, e ainda da sensibilidade de uma classe urbana escolarizada, o que imprime a essa atividade de lazer mais que uma marca de classe, um caráter ascético que nos remete ao âmbito da devoção, como etnografado por Steil e Toniol (2011) nas experiências de caminhada em Rio Grande do Sul. Para esses autores, atitudes "responsáveis" em relação ao meio ambiente vêm constituindo uma "ascese ecológica" por parte de sujeitos e coletivos ecologicamente orientados que, ao incorporarem sistemas de crenças, terminam por promover uma sacralização da natureza (Ibid.).

É em função da sacralização de um espaço tido como "natural" que as "poluições" são exaltadas e denunciadas. Assim, Menezes lamenta-se tanto da insegurança em alguns trechos como da "sujeira" deixada pelas

ansiosos pelas placas e setas, que espalhadas pelo trajeto, ensinam o caminho aos menos versados na arte de trilhar. Entre estes últimos, os acidentes e os atos de vandalismo são os mais comuns. Não estão ainda acostumados à Floresta. Perdem-se por falta de atenção ou por excessiva ousadia, roubam a sinalização para servir-lhes de souvenir, e provar à namorada faceta Indiana Jones. Passamos por muitos deles, alguns tão animais e selvagens quanto a fauna que poderiam observar se caminhassem mais lentos e cuidadosos. Vem desembestados trilha abaixo a urrar gritos de guerra (...)Também há aqueles vestidos com calça de brim e saia rodada, chinelo de dedo e sandália aberta (...) aventuram-se dez, quinze minutos no máximo- terão histórias para contar durante vinte anos." (Ibid; p. 84) 
oferendas feitas pelos praticantes das religiões de matriz africana. Deplora o crescimento das favelas tanto quanto a presença das culturas tradicionais do maciço, encaradas como as grandes vilãs da floresta. "A pesar dos esforços de Marcelo o do IEF as plantações de caqui e banana parecem aumentar - é muito difícil reverter uma cultura secular que já deflorou a Pedra Branca em três ciclos econômicos prévios (...)" (MENEZES, 2000; p.38).

Sob a premissa do turismo como gerador de emprego, Menezes propõe a dedicação dos atuais moradores à recepção, alimentação e hospedagem de caminhantes, cujos serviços incrementariam a renda local de tal forma que lhes permitiria abandonar as atuais atividades agrícolas, mitigando assim os "impactos" da sua própria presença. Na conversão de espaços naturais em provedores de serviços de lazer e ócio está implícito o entendimento de que visitantes são aliados "naturais" à conservação, mais que os próprios moradores.

Na história ambiental do maciço, os usos nativos do espaço têm sido perseguidos e hostilizados (FERNANDEZ, 2009), e vistos como uma "não ecologia", isto é, uma "ausência de", ao invés de "a presença de uma ecologia nativa alternativa ou de um entendimento peculiar do mundo" (MANHÃES 2003; p.220). Ainda que algumas dessas atitudes repressoras tenham sido diminuídas pelas recentes gestões do PEPB, todavia, persistem percepções que assumem os agricultores como problema, termo presente no plano de manejo e nas falas espontâneas de alguns ambientalistas. Nas ideias por trás da implantação das trilhas por vezes emergem percepções da natureza que continuam a perpetuar uma separação natureza/cultura que opera sob uma visão que atribui um sentido de externalidade ao sujeito humano em relação ao mundo, configurando o mundo como o objeto de um sujeito fora dele e, como tal, objeto de intervenção, fiscalização, contemplação. Ao descrever a caminhada que realizou pela Estrada do Sacarrão até o Pau da Fome, Menezes afirma que esse trecho sintetiza os problemas do parque. Na única menção feita aos agricultores do maciço Menezes, propõe seu "tombamento" num tipo de visão ambígua que exotiza os camponeses, mas condena sua produção agrícola, base do seu sustento.

Até a cota de 250 metros são várias as casas de sitiantes. Construções toscas e feias em pau a pique, com puxados em alvenaria. Chão de terra batida, fogão a lenha apanhada no próprio Parque e colunas de madeira nativa a sustentar varanda de zinco. Uma rede a guisa de cama. Pendurados no teto, sacos de arroz, feijão, farinha... Porcos, cabritos e uma malta de cachorros magrelos a latir despeitados para os excursionistas (...) Não raro, cruzamos 
como com uma tropa de burros carregados de banana, caquis ou algum outro produtos sendo escoado para a feira. Cena cristalizada na historia da cidade, retratada por Debret e os sábios viajantes do inicio do século XIX, repetido por Magalhães Correa em seu celebre relato da Zona Oeste da era Vargas e viva ainda hoje, como nos idos da 1921 de Lima Barreto (...) Pudesse o IPHAN tombar gente e devíamos todos nós pôr a clamar pelo tombamento dessas tropas e tropeiros tão parte do fazimento do Brasil (MENEZES 2000; p.45).

De pé, retomamos a cabritada, trocamos de encosta. O lado de lá dói- de dar pena, é todo degradado, coberto de pastos, plantações de caqui e outras lavouras. A terra, que se quer pública, esquartejada e dividida em fazendolas protegidas por montes de arame farpado. As trilhas, rústicos caminhos de escoamento da produção (MENEZES, 2000; p.52).

Mas nem todas as obras e construções humanas causam no autor o mesmo sentimento. A sofisticação de exemplares da arquitetura europeia oitocentista, em pé no meio da floresta, lhe causa, pelo contrário, admiração, dada a possibilidade de recontar a história a partir da presença de mansões e casarões de viscondes e mecenas de arte que moraram no Rio de Janeiro. Para essas "casas espetaculares", hoje em ruínas, o autor almeja sua transformação em albergues para os trilheiros, e o mesmo destino é sugerido para a conhecida Casa Amarela, localizada nas proximidades de Pau da Fome. Nessa linha de raciocínio, não estranha que a única simetria entre homem e natureza encontrada por Menezes seja a atual casa sede do parque, localizada em Pau da Fome, à qual se refere como

(...) um exemplo de perfeita harmonia entre a natureza e a construção humana. A sede do Parque, toda de madeira, saiu da prancheta do arquiteto Zanini, um artista que faz a integração entre ambiente e prédio parecer natural. Sua obra, por si só, já valeria a visita, pois nos deixa entrever a possibilidade de também um dia eliminar a oposição entre homem e floresta, mesclando-os com a mesma poesia da sua arquitetura (MENEZES, 2000; p.49).

Por trás das tais considerações, percebe-se uma concepção de paisagem que separa homem e natureza, mas visualiza sua comunhão mediante um saber especializado e acadêmico, desconhecendo a variedade de formas em que a paisagem está implicada nos atuais moradores e seus estilos de vida, que também são a paisagem (GOW, 1995). 


\section{Sinalização, Divulgação e os Conflitos das Perspectivas}

Segundo a página Mosaico Carioca ${ }^{11}$ (MC) ${ }^{12}$, a divulgação da trilha vem sendo feita mediante redes sociais e diversos veículos de mídia impressa, televisão e websites, além de folhetos, mapas, camisetas, banners informativos e encontros. Em maio de 2013, o MC organizou "Trilha Transcarioca: Seminário Internacional de Trilhas de Longo Curso", reunindo cerca de duzentos convidados entre especialistas, pesquisadores, montanhistas e gestores de unidades de conservação que participaram de oficinas técnicas para debater segurança, comunicação, sinalização, manejo, divulgação, geração de emprego e renda, assim como o traçado da Trilha em seus diferentes trechos. Ocasião da qual nenhum morador da área do parque participou.

Em dezembro de 2014, aconteceu o $1^{\circ}$ Encontro para o Diálogo entre comunidades agrícolas e tradicionais e parques do Mosaico Carioca ${ }^{13}$. Foi o momento em que, depois de 40 anos de fundação do parque, os moradores da área tiveram pela primeira vez a oportunidade de se encontrar num espaço de participação com os gestores do PEPB no INEA. Entre vários temas, a Transcarioca apareceu sobre a mesa do debate. Para seus promulgadores, a Trilha Transcarioca era um fato sem discussão, dados os múltiplos e incontestáveis benefícios. Benefícios para quem? perguntaram os moradores presentes. Para fazer conhecidas as áreas protegidas e incentivar entre a cidadania sua preservação, responderam os gestores, que ainda acrescentaram que a comunidade poderia se beneficiar com a criação de um mercado de produtos locais, os quais poderiam ser oferecidos aos caminhantes e turistas.

No verão de 2015-2016, o número de caminhantes e banhistas multiplicouse e, com ele, quantidades alarmantes de lixo não recolhido. As críticas ao projeto da Transcarioca adquiriram tal força nas redes sociais que os gestores do PEPB terminaram mediando uma reunião entre os moradores e

\footnotetext{
${ }^{11}$ http://mosaico-carioca.blogspot.com.br/p/trilha-transcarioca.html, consultada em 23 de março de 2015.

${ }^{12} \mathrm{O}$ Mosaico Carioca de Áreas Protegidas faz parte de um programa incentivado pelo MMA com base jurídica através do sistema Nacional de Unidades de Conservação (SNUC) e tem como objetivo a integração de ações entre as Áreas Protegidas envolvidas.

${ }^{13}$ Parque Estadual da Pedra Branca e Parque Estadual do Mendanha.
} 
os idealizadores da trilha. Nessa reunião, Menezes apresentou o projeto da trilha como uma iniciativa essencialmente voluntária, feita com os recursos e o tempo livre de voluntários ativos e das redes sociais, assim como de caminhantes e montanhistas, calculados em oito mil pessoas.

Com base nessa estimativa, Menezes defendeu o seu projeto como uma iniciativa "popular", criada, segundo suas palavras, "de baixo para cima". Ao ser questionado sobre os contornos da sua definição de "popular" e a legitimidade dessa representatividade que excluía moradores, Menezes afirmou que o fato de os moradores não concordarem com o traçado da trilha não seria um fator que viria a afetar a "popularidade" de uma proposta que preza, antes de mais nada, pelo direito da cidadania ao uso de uma área pública. Para ele, o caráter popular emana do fato de ser uma iniciativa independente das diretrizes dos órgãos ambientais do Estado. Contudo, o Estado não pareceu, nessa reunião, muito independente do projeto, já que alguns funcionários decidiram vestir nesse dia a camiseta da Trilhas Transcarioca.

O espaço dessa reunião também foi aproveitado para debater impactos negativos da agricultura e motivar a população nativa a se preparar para vender comida, carregar equipagens e recepcionar caminhantes que quisessem pernoitar nas suas casas, mas advertindo, paradoxalmente, que nenhuma "melhoria", como ampliação ou remodelação, poderia ser feita nas casas existentes. Menezes sugeriu então que um cômodo dentro das casas fosse cedido e adequado para esse fim. Essa proposição causou constrangimento entre os moradores presentes, que assim constataram o estabelecimento oficial de relações transitórias, mas totalmente assimétricas entre a população anfitriã e os futuros visitantes que fruiriam desses serviços.

Muito tempo antes de essas reuniões terem lugar, a Transcarioca já tinha deixado suas marcas no território. No livro de Menezes e no manual de trilhas do PEPB é reiterada a necessidade de sinalização das trilhas seguindo técnicas internacionais de demarcação. O objetivo, além de orientar o caminhante para a direção correta, é também facilitar ações de manejo, evitando processos erosivos, impedir a criação de atalhos, e desestimular o pisoteio de áreas sensíveis, dentre outros benefícios ambientais.

Para a Trilha Transcarioca foi escolhida, como logomarca oficial da trilha, uma pegada de bota de caminhante que, no meio, tem a figura de um emblemático Cristo Redentor carregando uma mochila (figura 2). A demarcação das trilhas é feita mediante a convocação de mutirões pelas redes sociais: deles participam caminhantes, amantes da natureza, guarda- 


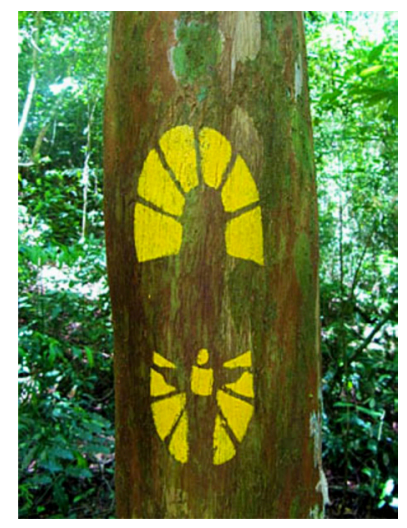

Figura 2 - Pegada de bota com a figura do Cristo Redentor carregando uma mochila nas costas.

Fonte: Luz Stella Rodríguez

parques e os idealizadores do projeto. Muitos dos moradores não sabiam que as logomarcas estampadas em pedras e árvores correspondiam a um sistema de sinalização de trilhas. Foi por meio de jornais e comentários nas redes sociais que os moradores descobriram os autores e propósitos daquelas marcas nos caminhos feitos, praticados e mantidos por eles e seus ancestrais.

A execução da Trilha Transcarioca trouxe à tona elementos da relação tensa que tem existido entre os moradores do maciço e os gestores do parque. As falas dos moradores expressam as novas nuances que esse conflito assume. Um dos agricultores contou que, numa ocasião, as marcas para o caminho do Gunza foram feitas logo depois que seu irmão o roçou com a finalidade de escoar a banana que tinha nesse setor. Entendendo de que se tratavam essas marcas, questionou: vem cá, quem reconhece esse nosso trabalho? Naquela roçada foram investidos três dias de trabalho, assim fica mole demarcar, né? Quem é que leva o crédito por isso?

Como é possível? Se pergunta um outro agricultor, se a gente aqui é multado pelo parque até por roçar, e agora vêm pintar pezinhos no meio da roça da gente. Por que não há um ganho para o agricultor que de fato mantém esses caminhos? É a gente que conhece, é a gente que cuida. A indignação frente ao tratamento que os moradores tradicionais têm recebido por parte dos gestores do parque reaparece em narrações ligadas à manutenção dos caminhos do maciço. Um causo contado pelo agricultor Pedro resume bem o paradoxo da conservação frente às necessidades das populações locais.

Era 1999 e, cansado do estado da via acidentada e esburacada e dos danos causados à sua kombi, Pedro decidiu ajeitar o caminho, continuação da rua Cleodon Furtado, que, por sua vez, é continuação da Estrada Mucuíba. A empreitada de Pedro iniciou-se num ponto conhecido como a mansão do piloto e ia até o rio Paineiras. Fazer transitável o caminho era urgente para Pedro, por ser ele mesmo o comerciante da sua produção na feira. Foi um trabalho de longos meses com várias etapas, efetuado ora sozinho, ora em mutirão, ora com o tio, ora com o filho para empedrar e cimentar. Nos trajetos mais difíceis, teve que contratar um trator e adequar manilhas para canalizar as águas dos córregos.

Pela perspectiva do habitar, vimos que só é possível habitar aquilo 
que se constrói. "Este, o construir, tem aquele, o habitar, como meta" (HEIDEGGER, 2002; p.1). E esse habitar nativo tem sido posto em xeque desde a implementação do PEPB no maciço. Assim sendo, a melhoria do caminho não passou invicta ante os órgãos fiscalizadores do PEPB: Pedro guarda na sua memória várias multas e três idas à cadeia por crime ambiental. Para ele e sua família, não deixa de causar indignação que, depois daquela saga, esse caminho pelo qual foi tão condenado e multado apareça hoje como uma das formas de acesso às cachoeiras e aos poços no manual de trilhas do PEPB com a chancela do INEA. Na "Travessia do Vale de Gunza", um dos recorridos sugeridos no livro explica como acessar as cachoeiras, uma possibilidade que hoje se dá pelo trabalho de Pedro e sua família, mas ao que não se faz menção.

(...) Siga pela Estrada do Pacuí até o no 931 e entre à direita na Estrada do Mucuíba, seguindo até pouco depois do no 918 para entrar na próxima rua à esquerda, em uma bifurcação. Caso venha de carro e queira subir até o início das quedas, nessa bifurcação siga pela direita, subindo a Estrada do Mucuíba até seu final. Após entrar à esquerda, vá caminhando pela estradinha de calçamento de pedra e logo entre novamente à esquerda, onde começa a tornar-se de terra. Continue sempre no caminho principal em aclive. Após algumas casas, a estradinha fica cada vez mais precária, até se transformar em uma trilha, perto da cota 100. Minutos depois já poderá visitar o primeiro poço desse roteiro, em uma entradinha à esquerda da trilha. Depois de $500 \mathrm{~m}$ do poço há um larguinho e três opções de caminho. $\mathrm{O}$ caminho mais à direita é o final da Estrada do Mucuíba, de onde se optou por seguir pela trilha para chegar até aqui, mas quem vier de carro pode seguir pela estrada até esse ponto. $\mathrm{O}$ caminho mais à esquerda, atravessando uma ponte para oeste, na direção de algumas casas, é um antigo caminho colonial chamado de "Caminho do Cafundá", que segue em direção a Campo Grande, e onde é possível fazer uma conexão com o final do "Caminho da Mangalarga", (...) formando outro interessante circuito. Para o Vale do Gunza, seguir o caminho do meio, sentido nordeste, em uma trilha mais estreita, porém ainda bem marcada, continuando em paralelo ao Rio da Divisa, que desce essa escarpada encosta da serra formando uma série de cachoeiras e poços que convidam a uma visitação (INEA, 2013; p.239). negrito meu.

O ponto de confronto entre a perspectiva nativa e a atual promoção do lazer reforça as assimetrias que caracterizam a relação entre os gestores do 
parque e os moradores tradicionais do maciço da Pedra Branca, pois o rigor da aplicação das leis de proteção tem como alvo preferencial a população tradicional, sem atingir da mesma forma outras camadas sociais. Para esses moradores e pequenos agricultores, um exemplo do que bem pode se chamar de racismo ambiental (HERCULANO; PACHECO, 2006) está nos casos dos moradores mais abastados que construíram dentro do parque e imediações mansões de luxo com piscinas sem maiores empecilhos. Estes não tiveram as sanções, multas e notificações que a população tradicional enfrenta quando tenta remodelar ou melhorar suas casas e caminhos. A narração desse confronto reflete uma clara reação aos excessos, ou absurdos, no que tange às exigências dos órgãos de controle ambiental aplicadas à população tradicional.

O choque com o projeto é considerável, tendo em vista a forma como sua implantação vem sendo feita, sem consulta nem participação. Ainda que seus idealizadores apresentem a Transcarioca como um projeto feito de baixo para cima, para os moradores tradicionais o projeto opera na direção inversa, como uma proposta de cima para baixo. Contudo, é necessário ressaltar que os moradores não se opõem à chegada dos visitantes - como já foi dito, "visitante é bem-vindo". Mas questionam ficar à margem do projeto, não serem considerados aliados e parceiros, nem reconhecidos como conhecedores do local e, mais precisamente, responsáveis pela existência de muitos desses caminhos, envolvidos em epistemologias e saberes diferentes, e agora chamados trilhas. Os moradores querem participar em nível decisório e não apenas carregar as bagagens dos turistas.

\section{Considerações Finais}

A tensão entre as perspectivas do habitar e do lazer tem como marco uma população tradicional afetada pela transformação de seu lugar em unidade de conservação ambiental. O conflito de visões e interesses entre os moradores e a população urbana que pretende usufruir da chamada oferta ambiental da cidade tem como ponto de partida experiências ambientais e "expectativas de natureza" diferentes e, portanto, não universalizáveis, em que as agendas particulares e do Estado e a imposição de políticas e cobrança de cumprimento das leis ambientais têm um papel relevante.

Considerando as narrativas locais sobre os caminhos e as formas nativas de identificação do espaço, a implantação de trilhas e de sua política de manejo 
representa uma divergência com os modos de vida locais que produziram, a partir das suas práticas e experiências, uma sintaxe espacial particular: o caminho, cujas flexíveis toponímias locais carregam histórias e narrativas. Além de estabelecer mediações entre espaços públicos e privados e conectar profundamente a população local à cidade, o caminho é a materialização das relações de parentesco na paisagem. Porém, dita materialização não é automática nem permanente. $\mathrm{O}$ caminho precisa de trabalho humano constante, cria mutirões e exige das pessoas sua presença, recursos e tempo para assim efetivar as mediações que lhe foram conferidas. Assim, os caminhos organizam relações sociais em prol de sua manutenção.

Na medida em que o caminho é, também, uma mediação entre o rural e o urbano, o surgimento da trilha está ligado à promessa de alcançar a "natureza", distanciando-se da cidade, separando prazer de trabalho, e se tornando um fim em si mesma. Nessa procura, a noção de espaço público repercute nas práticas de lazer, apostando numa paisagem posta exclusivamente ao serviço da recreação urbana alimentada por ideias purificadas de natureza.

Mais que o confronto decorrente entre códigos distintos de relacionamento com a natureza, o caso do projeto da Trilha Transcarioca também sumariza os efeitos do desenho de políticas ambientais que continuam partindo, na prática, de uma certa ideia de vazio populacional da paisagem do maciço. A presença dos moradores, quando não é problemática, é ressaltada como folclórica, passível de musealização.

Como foi exposto, ainda que a trilha esteja vinculada às áreas de proteção ambiental, sua origem no maciço da Pedra Branca encontra-se ligada aos caminhos de ocupação histórica da cidade de Rio de Janeiro. Assim, a origem dessas trilhas está vinculada a um modo de vida rural que ainda persiste e que precisa ser reconhecido.

\section{Referências}

ANDRADE, W. (2005). Implantação e manejo de trilhas". Manual de Ecoturismo de Base comunitária, ferramentas para um planejamento responsável. Brasília: WWF Silvia Mitraud.
AUGÉ, M.

(2009). Los 'no lugares', espacios del anonimato. Una antropología de la sobremodernidad. [en línea] Xalpa, Al Fin Liebre Ediciones Digitales. Disponivel em: www.latrampademirabilia. blogspot.com. Acesso em 20 de março de 2015. 
BARRETTO, M.

(2003). 0 imprescindível aporte das ciências sociais para o Planejamento e a compreensão do turismo. Horizontes Antropológicos, ano 9, n. 20; p. 15-29.

CARVALHO, S.

(2015). Divulgar ou não divulgar, eis a questão. In: 0 Sertão Carioca. Disponível em http:// ecomuseusertaocarioca.blogspot.com. br/2015/03/o-sertao-carioca-por-sergio-decarvalho.html . Acesso em 25 de março de 2015.

DA COSTA, V. C.

(2006). Propostas de Manejo e Planejamento Ambiental de Trilhas Ecoturísticas: Um estudo no Maciço da Pedra Branca Município do Rio de Janeiro. Tese de Doutorado apresentada ao Programa de Pós-Graduação em Geografia da Universidade Federal do Rio de Janeiro.

DE CERTEAU, $M$.

(2013). Relatos de espaço. A invenção do cotidiano. Vol. 1. Rio de Janeiro: Ed. Vozes.

FERNANDEZ, A.

(2009). Do Sertão Carioca Ao Parque Estadual Da Pedra Branca: A Construção Social de uma Unidade de Conservação à Luz Das Políticas Ambientais Fluminenses e da Evolução Urbana do Rio De Janeiro. Tese de Doutorado apresentada ao Programa de Pós-Graduação em Sociologia da Universidade Federal do Rio de Janeiro.

\section{FUNBIO.}

(2012). Edital de Contratação de empresa para a elaboração de projetos para implantação de trilhas e atrativos dos Parques Estaduais da Copa 2014. Disponivel em: http://www. funbio.org.br/?s=implanta $\% \mathrm{C} 3 \% \mathrm{~A} 7 \% \mathrm{C} 3 \% \mathrm{~A} 3$ $0+$ das+trilhas+e+atrativos+dos+Parques+Est aduais $+d a+C o p a+2014 \&$ cat $=0$. Acesso em 15 de outubro de 2014.

GOW, P.

(1995). Land people and paper in western Amazonia. In: Eric Hirsch and Michael $0^{-}$ Hanlon (Eds.); The Anthropology of Landscape. Perspectives on Place and Space). 0xford: University Press.
HEIDEGGER, M.

(2002). Construir, Habitar, Pensar. In: Ensaios e Conferências. (trad.) Márcia Sá Cavalcante Schuback. 2. ed. Petrópolis: Vozes.

HERCULANO, S.; PACHECO, T. (Org.).

(2006). Racismo ambiental, o que é isso?. I Seminário brasileiro contra o racismo ambiental. Rio de Janeiro: FASE.

ILHA, André; CASTRO, Patrícia Figueiredo de; PEDROS0, Alexandre Marau; SCHNEIDER, Aline (Orgs.).

(2013). Trilhas: Parque Estadual da Pedra Branca/Instituto Estadual do Ambiente. Rio de Janeiro, INEA.

INGOLD, T.

(2011). Being alive: essays on movement, knowledge and description. New York: Routledge.

(2000). The temporality of the landscape. In The perception of the environment: essays on livelihood, dwelling and skill. Londres: Routledge.

LATOUR, B.

(2008). Reensamblar lo Social: una introducción a la teoría del actor-red. Buenos Aires: Manantial.

LÉVI-STRAUSS, C.

(1976). O pensamento selvagem. São Paulo: Companhia Editora Nacional.

MAGALHÃES CORREA, A.

(1936). Sertão Carioca. Revista do Instituto Histórico e Geográfico Brasileiro. Rio de Janeiro, Volume 167.

MAGNANI, J. G.

(2000). Quando o campo é a cidade. In: José Guilherme Magnani; Lillian de Lucca Torres (Orgs.); Na metrópole: textos de antropologia urbana. São Paulo, EDUSP/FAPESP.

MANHÃES, R. P.

(2003). As Espécies Exóticas Somos Nós: Reflexão a Propósito do Ecoturismo na Ilha Grande. Horizontes Antropológicos, ano 9, n. 20. 
MAUSS, M.

(1974 [1923-24]). Ensaio sobre a dádiva. Forma e razão da troca nas sociedades arcaicas. Sociologia e Antropologia. v. II. São Paulo: Edusp.

MENEZES E CUNHA, P.

(2000). Transcarioca: todos os passos de um sonho. Rio de Janeiro: Sextante.

(1998). Trilhas do Rio. Rio de Janeiro: Salamandra.

MERLEAU PONTY, M.

(1976). Phénomólogie de la perception Paris: Gallimard.

JORNAL 0 DIA.

(15 de dezembro de 2012). Supertrilha será a maior em área urbana do mundo. Disponível em: http://odia.ig.com.br/ portal/r io/super trilha-ser\%C3\%A1-a-maior-em-\%C3\%A1reaurbana-do-mundo-1.526458\#commentsfacebook . Acesso em 15 de agosto de 2014.

\section{RODRIGUEZ, L. S.}

(no Prelo, 2016). Pelos Caminhos do Cafundá. Paisagem, Memória e Parentesco no Quilombo da Vargem Grande. Annelise Fernandez; Rogério Ribeiro de Oliveira (Orgs.); Paisagens do Sertão Carioca: homem, floresta e cidade Rio de Janeiro.
SALVATI, S.

(2003). Trilhas, conceitos, técnicas de implantação e impactos. Ecosfera. Disponível em: www.ecosfera.site.uol.com.br/trilhas. htm . Acesso em 21 de setembro de 2003.

STEIL, C. A.; TONIOL, R.

(2011). Ecologia, Corpo Espiritualidade. Uma etnografia das experiências de caminhada ecológica em um grupo de ecoturistas. Caderno CRH, v. 24, n. 61.

URRY, J.

(2001). 0 Olhar do Turista. 2001. Editora Studio Nobel/SESC: São Paulo.

\section{Recebido em}

abril de 2015

Aprovado em

maio de 2016 